\title{
As metrópoles do interior do Nordeste: a caracterização de um tipo metropolitano regional
}

\author{
The metropolises of the interior of northeastern Brazil: \\ characterizing a regional metropolitan type
}

Ana Paula Campos Gurgel

\section{Resumo}

0 objetivo deste trabalho é apresentar como as configurações dão suporte à constituição do que se denominou Regiões Metropolitanas no Interior do Nordeste (RMINEs), buscando a caracterização de um tipo metropolitano regional. Nas últimas décadas, a urbanização cresceu nas cidades médias e nas franjas perimetropolitanas, convertendo esses territórios em polos de atração de migrações internas e inter-regionais. A pesquisa abrange as RMINEs com mais de 500.000 habitantes com indícios de conurbação física. Tais áreas são caracterizadas por seu estágio intermediário de metropolização em relação às grandes metrópoles nacionais, congregando equipamentos, serviços e empregos que atendem a uma escala regional e que, portanto, representam uma dominância socioeconômica e funcional dessas cidades-sede sobre suas hinterlândias.

Palavras-chave: morfologia; metropolização; cidades médias; nordeste.

\begin{abstract}
The objective of this work is to present how configurational properties support the constitution of what is called Metropolitan Regions in the Interior of Northeastern Brazil (RMINEs), in an attempt to characterize a regional metropolitan type. In recent decades, urbanization has grown in medium-sized cities and perimetropolitan fringes, converting these territories into poles of attraction of internal and inter-regional migrations. The study covers RMINEs with more than 500,000 inhabitants and signs of physical conurbation. These areas are characterized by their intermediary stage of metropolization in relation to large national metropolises, bringing together equipment, services and jobs that serve a regional scale and, therefore, represent a socioeconomic and functional dominance of these cities over their hinterland regions.
\end{abstract}

Keywords: morphology; metropolization; medium-sized cities; northeast. 


\section{Introdução}

O fenômeno metropolitano é recorrente na narrativa urbana. Sua etimologia' remete à Grécia Antiga, empregada para uma cidade progenitora de outras em uma relação de dependência. Portanto, a metrópole exercia um domínio sobre um determinado território por meio da oferta de bens e de serviços distintos para uma região. Este é o cerne para compreender o fenômeno da metropolização, entendido como uma interdependência funcional entre a cidade-núcleo e outros municípios e exemplificado por um mercado de trabalho com mais oportunidades e maior oferta de equipamentos urbanos e serviços. De acordo com o exposto em Teixeira (2005), as RMs são compostas por um conjunto de municípios cujas áreas urbanas unem-se com certa continuidade, caracterizadas ainda por alta densidade demográfica e que compartilham familiaridades socioeconômicas que devem ser coordenadas por uma ação governamental conjuntamente planejada.

Muito se fala das grandes metrópoles ou megacidades, mas apenas um a cada oito habitantes está nesses centros, enquanto cerca de 1,9 bilhão de habitantes reside em aglomerações com até 500 mil habitantes (ONU, 2014). E estas são as cidades que apresentam maior taxa de crescimento. No Brasil os dados não são discrepantes: as cidades de porte mediano ${ }^{2}$ no cenário econômico e na rede urbana brasileira têm destaque desde a década de 1970 e seu fortalecimento é evidenciado pelo processo de desconcentração da produção e da população no território nacional e nos últimos anos. Estas foram as cidades que apresentaram maior crescimento anual do Produto Interno Bruto(PIB) e crescimento mais elevado da população, dando origem a processos de metropolização.

A partir da Constituição Federal de 1988, passou-se aos estados a competência de versar sobre a organização regional como especificado no $\S 3^{\circ}$ de seu artigo 25, localizado no Título III, da Organização do Estado, Capítulo III, dos Estados Federados: "os Estados poderão, mediante lei complementar, instituir regiões metropolitanas, aglomerações urbanas e microrregiões, constituídas por agrupamentos de municípios limítrofes, para integrar a organização, o planejamento e a execução de funções públicas de interesse comum" (Brasil, 1988, s/p). Entretanto, a inexistência de critérios de delimitação e/ou de classificação de RMs e de uma política em âmbito nacional que versasse sobre a questão metropolitana resultou na implementação de regiões metropolitanas que são regiões, mas que não são necessariamente metropolitanas (Firkowski, 2012) visto que refletem motivações e interesses estaduais. Até o Censo Demográfico de 2010, estavam institucionalizadas 36 Regiões Metropolitanas (RMs) e três Regiões Integradas de Desenvolvimento - (RIDes).

Embora não caiba, nos objetivos deste estudo, averiguar a fundo os motivos por trás do componente político da constituição das RMs, é impossível negar que a emergência desses novos conjuntos espaciais como centros de polarização do desenvolvimento regional reflete o dinamismo socioespacial do interior do País. Complementarmente, as transformações no sistema econômico brasileiro decorrentes da implantação do modelo neoliberal que preconiza a redefinição do papel do Estado e abertura econômica, aliadas aos novos estágios do desenvolvimento tecnológico, trouxeram mudanças profundas na 
sociedade e, consequentemente, nas cidades e em sua hierarquização (Soares, 1998). Assim, as cidades médias assumem novos papéis, vislumbrados no expressivo crescimento populacional, enquanto, nas grandes metrópoles, as taxas têm paralisado ou decaído. Alguns autores (Armstrong e Mcgee, 1968; Santos, 1989 e 1993) afirmam que estaríamos presenciando um processo de involução metropolitana, enquanto outros destacam a disseminação do processo de metropolização para outros contextos urbanos.

Se nos aproximamos desse segundo viés, a hipótese norteadora deste estudo é que existem propriedades morfológicas intrínsecas que dão suporte ao processo de metropolização verificado em algumas das regiões metropolitanas do interior do Nordeste - RMINEs, embora nem sempre sejam essas características norteadoras da decisão de criar regiões metropolitanas no País. Além disso, devido ao viés político inerente à questão, acredita-se que algumas outras cidades nordestinas apresentem também padrões morfológicos de metropolização, mesmo que não sejam pertencentes a RMs. Essa hipótese subsidia uma segunda, na qual se acredita que haja um tipo metropolitano regional no interior do Nordeste, caracterizado por um processo de metropolização em estágio intermediário em relação às grandes metrópoles nacionais.

\section{Metropolização e rede urbana nordestina}

Os processos de metropolização têm se asseverado nas últimas quatro décadas, destacando uma cidade principal de uma região como elemento estruturador de toda a rede urbana. Essa predominância se dá, não apenas pela sua dimensão populacional e econômica, mas também pela execução de funções diversificadas, além de estabelecer relações econômicas com diferentes aglomerações/metrópoles. É a complexidade de suas funções que lhe assegura uma posição de comando sobre as demais aglomerações urbanas (Santos, 1967). Nesse sentido, as metrópoles constituem:

[...] centros do poder econômico, social e político. Portanto, são unidades capazes de polarizar o território nas escalas nacional, regional e local. Entre essas características, ressaltam-se a organização funcional dos espaços; a concentração/ distribuição de população, produto e rendimentos; os fluxos de mercadorias, população e serviços; as condições de infraestrutura urbana; os processos de ocupação territorial; as articulações de poder; entre outras. 0 processo de metropolização passa por tais características, e as transformações na natureza e na configuração espacial das cidades levam a níveis distintos de integração dos territórios a essa dinâmica. (Ribeiro, Moura e Delgado, 2012, p. 2)

Ante o exposto, destaca-se a inegável relação de dominância exercida por algumas cidades ante sua rede de influência. Essa acepção, presente desde a origem da palavra metrópole, supera as tradicionais delimitações populacionais ou de tamanho da mancha urbana - o que é condizente com o tipo metropolitano que se pretende caracterizar neste estudo. A partir desse entendimento, ganham destaque outras dimensões que representam a polarização metropolitana, por exemplo, social, política, econômica e por que não incluir 
também os aspectos morfológicos, numa perspectiva em que não é somente o tamanho físico ou populacional que facilita os acessos às infraestruturas da cidade e que produz as desigualdades socioespaciais.

A metropolização contemporânea é um fenômeno complexo que produz novas paisagens. Novas formas de morar e consumir, novos arranjos das forças produtivas e meios de produção rebatidos arquitetonicamente na construção dos edifícios e espaços urbanos, nas redes de circulação e transportes, entre outros, assinalam a materialidade espacial da metropolização. 0 câmbio diário dos meios de comunicação adiciona novos paradigmas imateriais a esse processo, por meio de plataformas que permitem o intercâmbio de informação em escala global e as maneiras pelas quais nos relacionamos com o outro.

Vivenciamos um novo estágio histórico da produção do espaço, não apenas como uma nova maneira de urbanização, mas a "metamorfose do processo de urbanização" (Lencioni, 2006). Do ponto de vista político, a metropolização pode ser vista com a "[...] hierarquização do espaço a partir da dominação de centros que exerce sua função administrativa, jurídica, parcelares cujo conjunto escapa ao indivíduo" (Carlos, 1994, p. 191). A metropolização vai além da concentração demográfica, diz respeito à multiplicação das aglomerações urbanas por meio da dilatação dos conteúdos metropolitanos que reproduzem as contradições do espaço. Esses processos globalizados já se embrenharam nos mais diversos confins do planeta. Incluo aí o Nordeste e suas reconhecidas problemáticas de desenvolvimento (pobreza, desigualdades sociais, baixa escolarização, recursos naturais limitados, dentre outros) que parecem se exacerbar diante das novas formas de (re)produção do capital, agrícola e urbana, impostas pelo mercado global.

A classificação e a gestão política das metrópoles brasileiras tiveram ao longo dos anos diversas intervenções em âmbito nacional e regional. Embora se justificassem por aliviar as disparidades socioeconômicas entrarregionais existentes, por meio de ações de descentralização de atividades econômicas e de população, pouco conseguiram pôr em prática, ou aquilo que foi feito atendia quase que exclusivamente aos interesses das oligarquias. Portanto, persiste a perpetuação histórica dos problemas regionais e intraurbanos, principalmente na dessemelhante dinâmica litoral e interior. Vários autores ressaltam a importância do aprofundamento do estudo das heterogeneidades com intuito de abrandar a desigualdade na hierarquia da rede urbana brasileira.

Nesse contexto, ainda, ressalta-se que as cidades de médio porte assumem importante papel na constituição das regiões metropolitanas. É importante destacar o seu potencial no desenvolvimento socioeconômico local, uma vez que tais cidades ofertam uma variedade de serviços, numa demanda regional, correspondente aos melhores indicadores sociais da região em que se inserem e que tem os requisitos para a criação e o desenvolvimento de polos tecnológicos. Ou seja, são alternativas à demasiada centralização industrial das regiões metropolitanas de grande porte, fatores que normalmente geram um aumento demográfico. Sua importância na rede urbana é visualizada como crescente entre os estudos do Ipea, IBGE, Unicamp (2001a, 2001b) e no documento Regiões de Influência das Cidades - Regic 
(IBGE, 2008), quando várias cidades mudaram de nível hierárquico. Seus processos de expansão urbana (algumas dos quais com evidências de conurbação física), a transformação e a modernização dos espaços intraurbanos são indícios que justificam a constituição das RMINEs. Entretanto, seu entorno compõe-se de municípios de pequeno porte, com capacidade financeira e de suporte social desigual, ou seja, são cidades que permanecem dependentes de serviços e infraestrutura oferecidos pela cidade-polo.

\section{Definição do objeto de estudo}

A primeira RMINE foi criada no Maranhão em 2005, sendo posteriormente instituídas outras a partir de 2009 (Tabela 1). Caso curioso é o do estado da Paraíba, que criou onze RMINEs, as quais, com exceção da RM de Campina Grande, organizam-se em torno de cidades de pequeno porte, sem indícios de crescimento demográfico, muito menos de metropolização - levantando novamente o problema da ausência de critérios nacionais de definições de RMs. Soma-se a esse mote a Região Administrativa Integrada de Desenvolvimento do Polo Petrolina e Juazeiro - Raid-PJ -, criada em 2001, que será tratada, neste estudo, como uma região metropolitana, apesar de abranger dois estados brasileiros. Dada a proliferação de RMs, especialmente na Paraíba e nas Alagoas, cabe adotar alguns critérios para a limitação desta pesquisa, visto que a máxima "são regiões, mas não são metropolitanas" (Firkowski, 2012) é claramente visível no caso nordestino. Para tanto foi preciso elaborar parâmetros para a seleção do universo desta pesquisa: (1) população; (2) posição na rede urbana; (3) indícios de conurbação física.

0 primeiro critério de seleção é o mais tradicional. Há relativo consenso na definição de cidades de porte médio como as que possuem entre 50.000 e 500.000 habitantes, ainda que esse intervalo esteja sujeito a alterações, cada vez que os resultados dos censos demográficos são divulgados (Spósito, 2010). Há, no Nordeste, 29 cidades médias, que congregavam, em 2010, uma população de 5,9 milhões de habitantes (IBGE, 2012). Entretanto, só o agrupamento de pessoas não é suficientemente claro como argumento para a definição de uma "cidade média", já que nos interessa especialmente entender o seu papel em sua rede urbana. A Regic 2007 (IBGE, 2008) estabelece uma hierarquia dos centros urbanos brasileiros. Neste estudo tenho interesse nas capitais regionais nível $\mathrm{B}$ e $\mathrm{C}$. Embora nem sempre se encaixem no critério populacional anterior, elas representam uma centralidade mediana na rede urbana e têm "[...] capacidade de polarizar um número grande de municípios no atendimento a bens e serviços de alta complexidade [...] concentram atividades de gestão pública e privada e articulam, na escala regional, órgãos e empresas privadas" (IBGE, 2013, s/p). A Tabela 1 apresenta todas as RMs do Nordeste já instituídas por lei e em vigência atualmente. Destaco, em negrito, aquelas que se enquadram nos dois primeiros critérios apresentados.

Por fim, o terceiro critério diz respeito à conurbação, entendida como a fusão de duas ou mais áreas urbanas em uma única, envolvendo integração física e funcional. Ou seja, uma conurbação exige, não somente a continuidade das malhas viárias, mas também uma relação de interdependência das cidades, 
Tabela 1 - Demonstrativo das RMs do Nordeste do Brasil

\begin{tabular}{|c|c|c|c|c|c|c|}
\hline Estado & $\begin{array}{c}\text { Denominação } \\
\text { da RM }\end{array}$ & $\begin{array}{l}\text { População } \\
2014\end{array}$ & $\begin{array}{l}\mathrm{N}^{\circ} \text { de } \\
\text { cidades }\end{array}$ & $\begin{array}{l}\text { Ano de } \\
\text { criação }\end{array}$ & Cidade-polo & $\begin{array}{c}\text { Regiões } \\
\text { de Influência } \\
\text { IBGE (2008) }\end{array}$ \\
\hline \multirow[t]{6}{*}{ Alagoas } & RM Maceió & 1.306 .251 & 14 & 1998 & Maceió & Capital regional A \\
\hline & RM Agreste & 508073 & 15 & 2009 & Arapiraca & Capital regional C \\
\hline & RM Zona da Mata & 303.236 & 15 & 2011 & União dos Palmares & Centro de Zona A \\
\hline & RM Vale do Paraíba & 210.751 & 13 & 2011 & Atalaia & Centro Local \\
\hline & RM Médio Sertão & 150.638 & 9 & 2013 & Santana do Ipanema & Centro sub-regional B \\
\hline & RM Palmeira dos Índios & 158.812 & 9 & 2012 & Palmeira dos Índios & Centro de Zona A \\
\hline \multirow[t]{2}{*}{ Bahia } & RM Salvador & 3.919 .864 & 13 & 1973 & Salvador & Metrópole \\
\hline & RM Feira de Santana & 739615 & 6 & 2011 & Feira de Santana & Capital regional B \\
\hline \multirow[t]{2}{*}{ Ceará } & RM Fortaleza & 3.818 .380 & 15 & 1973 & Fortaleza & Metrópole \\
\hline & RM Cariri & 590.209 & 9 & 2009 & Juazeiro do Norte & Capital regional C \\
\hline \multirow[t]{2}{*}{ Maranhão } & RM São Luís & 1.496 .100 & 6 & 2003 & São Luís & Capital Regional A \\
\hline & RM Sudoeste Maranhense & 351.653 & 8 & 2005 & Imperatriz & Capital regional C \\
\hline \multirow[t]{12}{*}{ Paraíba } & RM João Pessoa & 1.238 .914 & 12 & 2003 & João Pessoa & Capital regional A \\
\hline & RM Campina Grande & 630.777 & 19 & 2009 & Campina Grande & Capital regional B \\
\hline & RM Patos & 233768 & 24 & 2011 & Patos & Centro sub-regional A \\
\hline & RM Guarabira & 188.060 & 17 & 2011 & Guarabira & Centro sub-regional $A$ \\
\hline & RM Cajazeiras & 174671 & 15 & 2012 & Cajazeiras & Centro sub-regional A \\
\hline & RM Vale do Piancó & 148739 & 18 & 2012 & Piancó & Centro de Zona B \\
\hline & RM Esperança & 139576 & 9 & 2012 & Esperança & Centro local \\
\hline & RM Itabaiana & 135487 & 12 & 2013 & Itabaiana & Centro de Zona A \\
\hline & RM Vale do Mamanguape & 119049 & 9 & 2013 & Mamanguape & Centro de Zona A \\
\hline & RM Sousa & 116.093 & 9 & 2013 & Sousa & Centro sub-regional $\mathrm{A}$ \\
\hline & RM Barra de Santa Rosa & 80397 & 8 & 2012 & Barra de Sta. Rosa & Centro local \\
\hline & RM de Araruna & 66925 & 6 & 2013 & Araruna & Centro de Zona B \\
\hline Pernambuco & RM Recife & 3.887 .261 & 16 & 1973 & Recife & Metrópole \\
\hline R. G. do Norte & RM Natal & 1.473 .877 & 10 & 1997 & Natal & Capital regional A \\
\hline Sergipe & RM Aracaju & 912.647 & 4 & 1995 & Aracaju & Capital regional $\mathrm{A}$ \\
\hline $\mathrm{BA} / \mathrm{PE}$ & RAID - Petrolina-Juazeiro & 752433 & 8 & 2001 & Petrolina & Capital regional C \\
\hline $\mathrm{PI} / \mathrm{MA}$ & RIDe da Grande Teresina & 1.189 .260 & 14 & 2002 & Teresina & Capital regional A \\
\hline
\end{tabular}

Fonte: : Elaboração própria, em 2016, a partir das legislações estaduais, dados censitários da estimativa do IBGE/2014 e IBGE (2008). Obs.: em negrito destacam-se as RMs de interesse nesta pesquisa. 
que pode ser econômica, social e de serviços públicos urbanos, redes de infraestrutura e outros (Ferrari, 2004). Os critérios impostos reduziram drasticamente o número de aglomerações (são 20 RMINEs no total, segundo Tabela 1) a serem analisadas para somente cinco: (1) RM de Feira de Santana/BA; (2) RM do Cariri/ CE; (3) RM de Campina Grande/PB; e (4) Raid de Petrolina/Juazeiro.

Entre as aglomerações selecionadas, só o caso cearense e a Raid têm processos de conurbação em aparente estágio consolidado. Petrolina e Juazeiro, apesar da barreira física do Rio São Francisco, são ligadas por uma ponte, de modo que a fronteira político-administrativa interestadual não é um empecilho para que as cidades desenvolvam suas relações comerciais e se complementem nas funções urbanas (Araújo e Silva, 2013). 0 Crajubar, como é conhecida a aglomeração das cidades de Crato-Juazeiro do Norte-Barbalha, desde meados dos anos 1960, congrega hoje o maior adensamento populacional do interior do estado e compartilha uma mesma ambiência climática e cultural que as diferencia dos sertões nordestinos à sua volta (Gurgel, 2012). 0 seu processo de conurbação, acentuado a partir dos incentivos industriais dos anos 1990, é uma das justificativas que subsidiou a criação da RM, conforme descrito na lei complementar $n^{\circ} 78,26$ de junho de 2009.

\section{Avaliando as RMINEs}

Este artigo é parte de um estudo mais amplo que foi apresentado como tese de doutoramento (Gurgel, 2016), na qual os arranjos metropolitanos foram avaliados sob três vieses:
(1) de ordem socioeconômica; (2) de ordem configuracional; (3) do sistema de encontros e esquivanças, enquanto a sociedade é vista como artefato (Holanda, 2002). Aqui será apresentado um recorte, lidando com as variáveis de distribuição de renda e dedensidade habitacional e as expressões das áreas residenciais como suporte ao nosso argumento.

Para Villaça (2001), a segregação espacial das elites em determinadas áreas da cidade é uma das características mais marcantes das metrópoles brasileiras. Porém, estudos precedentes (Holanda, 2013; Medeiros, 2006; Carmo Júnior, 2014, dentre outros) demostram que nem sempre essa dicotomia entre ricos e pobres é tão clara, ou ainda, que as classes mais baixas nem sempre se localizam em áreas periféricas da mancha urbana. Optou-se por avaliar a questão em duas escalas: (1) numa escala regional, o Produto Interno Bruto - PIB total e per capita por RMs ou municípios; e (2) na escala dos setores censitários, o valor do rendimento nominal médio mensal das pessoas responsáveis por domicílios particulares permanentes espacializados no território municipal ou metropolitano.

Comparativamente, os PIBs são similares, com o menor deles na RM do Cariri/CE e o maior na RM de Feira de Santana/BA. Embora o Cariri represente o terceiro maior polo calçadista do Brasil (atrás apenas de Franca/SP e Novo Hamburgo/RS), cerca de $80 \%$ dos PIBs municipais advêm do setor terciário (IBGE, 2012), enquanto o município de Feira de Santana individualmente tem registrado, ao logo dos últimos anos, sucessivos crescimentos acima da média. Por exemplo, entre 2007 e 2011, o PIB de Salvador aumentou $45 \%$, enquanto o de Feira cresceu $75 \%$. Numa escala nacional, passou de 
Tabela 2 - PIB total das RMs, do município sede e per capita

\begin{tabular}{l|l|c|c|c|c}
\hline & Aglomerações/cidades & $\begin{array}{c}\text { População } \\
\text { Estimativas } \\
\text { IBGE/2014 }\end{array}$ & $\begin{array}{c}\text { PIB 2013 } \\
\text { (Total da RM) - } \\
\text { em mil reais - R\$ }\end{array}$ & $\begin{array}{c}\text { PIB 2013 } \\
\text { (Município sede) - } \\
\text { em mil reais - R\$ }\end{array}$ & $\begin{array}{c}\text { PIB per capita } \\
2013-\text { R\$ }\end{array}$ \\
\hline \multirow{2}{*}{ RMINE } & RM de Feira de Santana/BA & 786.086 & 13.059 .765 & 10.840 .566 & $16.613,66$ \\
& RM do Cariri/CE & 590.209 & 5.743 .833 & 3.221 .109 & $9.731,86$ \\
& RM Campina Grande/PB & 630.777 & 8.203 .666 & 6.538 .929 & $13.005,65$ \\
& RAID de Petrolina/Juazeiro & 752.433 & 9.247 .104 & 4.905 .327 & $12.289,60$ \\
\hline
\end{tabular}

Fonte: Elaboração própria, em 2016, a partir de dados coletados pelo IBGE (2013 e 2014). Disponível em: <http://cidades. ibge.gov.br>

$76^{\circ}$ município com maior PIB do País, em 2012, para $70^{\circ}$ em 2013. Isso se dá pelo dinamismo do setor terciário e pelo incremento na atividade industrial.

Para avaliar a distribuição de renda na escala municipal, foram utilizados os dados do censo de 2010 do IBGE, especificamente 0 V005 - Valor do rendimento nominal médio mensal das pessoas responsáveis por domicílios particulares permanentes (com e sem rendimento), apresentado na Tabela "Características da População e dos Domicílios". Como os dados são desvinculados das bases cartográficas, foi necessário o uso de ferramentas de geoprocessamento que permitiram observar a distribuição dos dados por setores censitários, resultando uma série de mapas que são apresentados na Figura 1.

Numa análise geral, verifica-se a concentração de renda nas cidades-sede das RMs. As exceções são a RM do Cariri/CE e a Raid Petrolina-Juazeiro. 0 Crajubar possui uma característica de conurbação que já ultrapassa a questão meramente espacial: as três cidades dividem, embora não de forma igualitária, as ofertas de emprego e a geração de renda com destaque para os maiores rendimentos no Crato e no Juazeiro do Norte/CE. No segundo caso, embora haja a predominância de maiores rendas em Petrolina/PE, Juazeiro/BA também possui indicadores maiores do que os demais municípios integrantes da Raid. Verificamos um nível de "conurbação" diferente das demais RMINEs, pois se percebe que Feira de Santana/ BA e Campina Grande/PB concentram os valores de rendimento nominal em relação aos demais municípios de seu entorno. Ou seja, temos dois tipos de RMINEs: (1) aquelas em que existe uma relação forte de independência entre dois ou mais municípios; e (2) aquelas em que a cidade-sede passa por um processo de crescimento que extravasa seus limites municipais.

Com relação às densidades, na RM de Feira de Santana/BA, o município-sede é responsável por cerca de $82 \%$ da população total da RM e, apesar de possuir o maior território (que representa cerca de $58 \%$ da área total da RM), também possui a maior densidade populacional. Vale ressaltar que Feira/BA é a segunda cidade mais populosa do interior do 
Figura 1 - Mapas de distribuição de renda (V005) por setor censitário
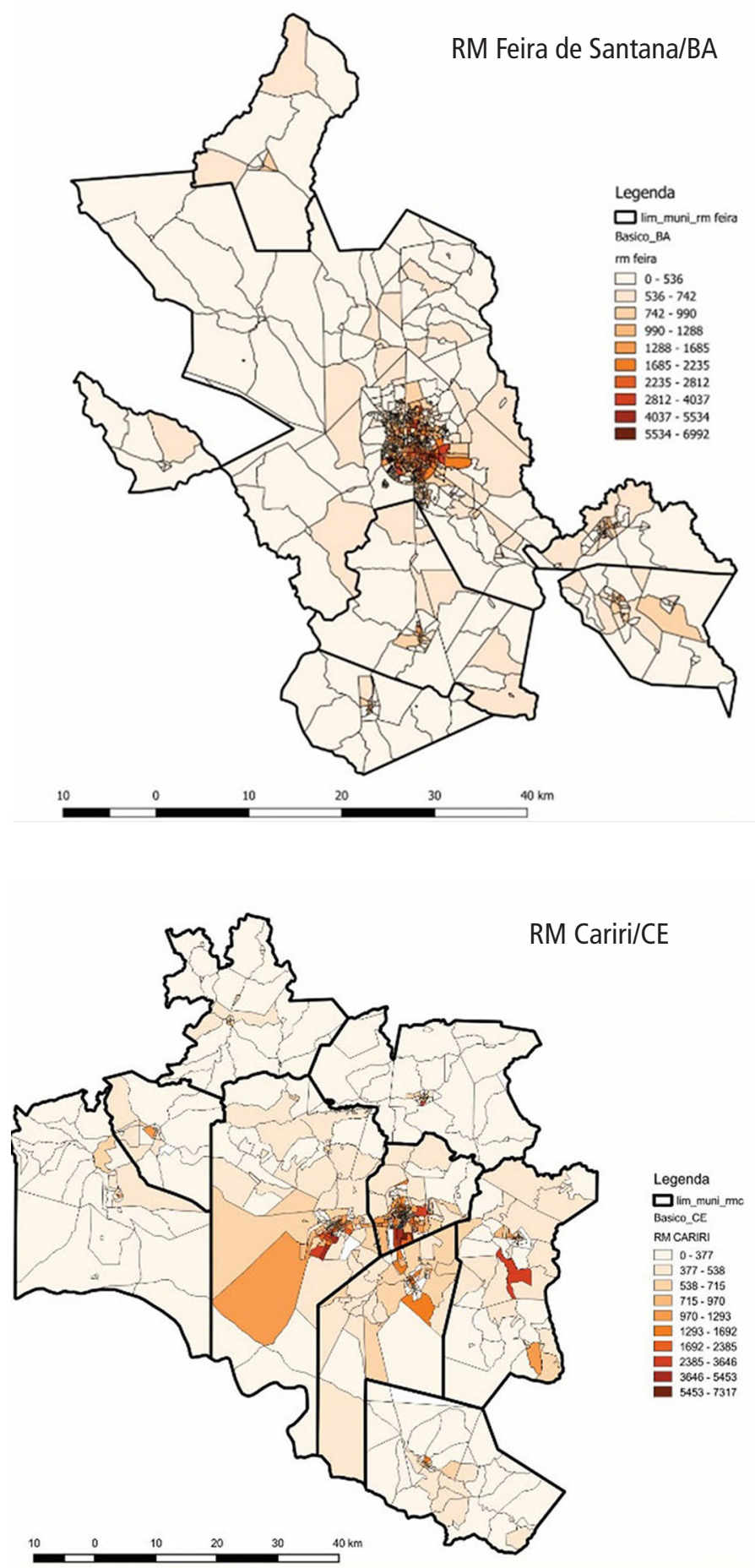


\section{RAID de Petrolina/Juazeiro}

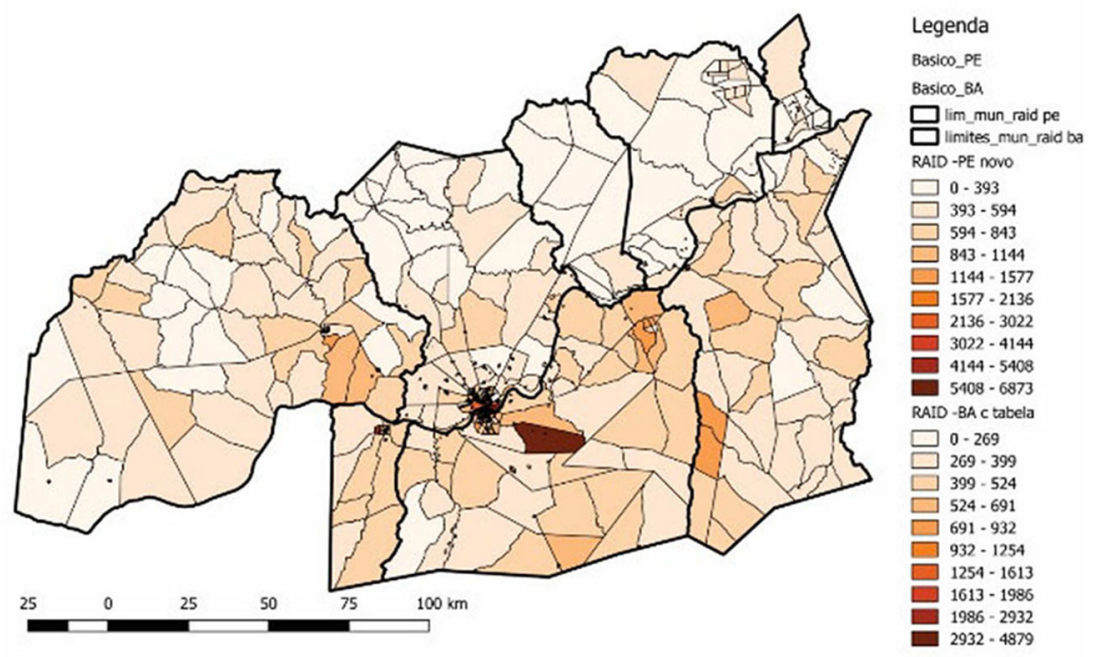

RM de Campina Grande/PB

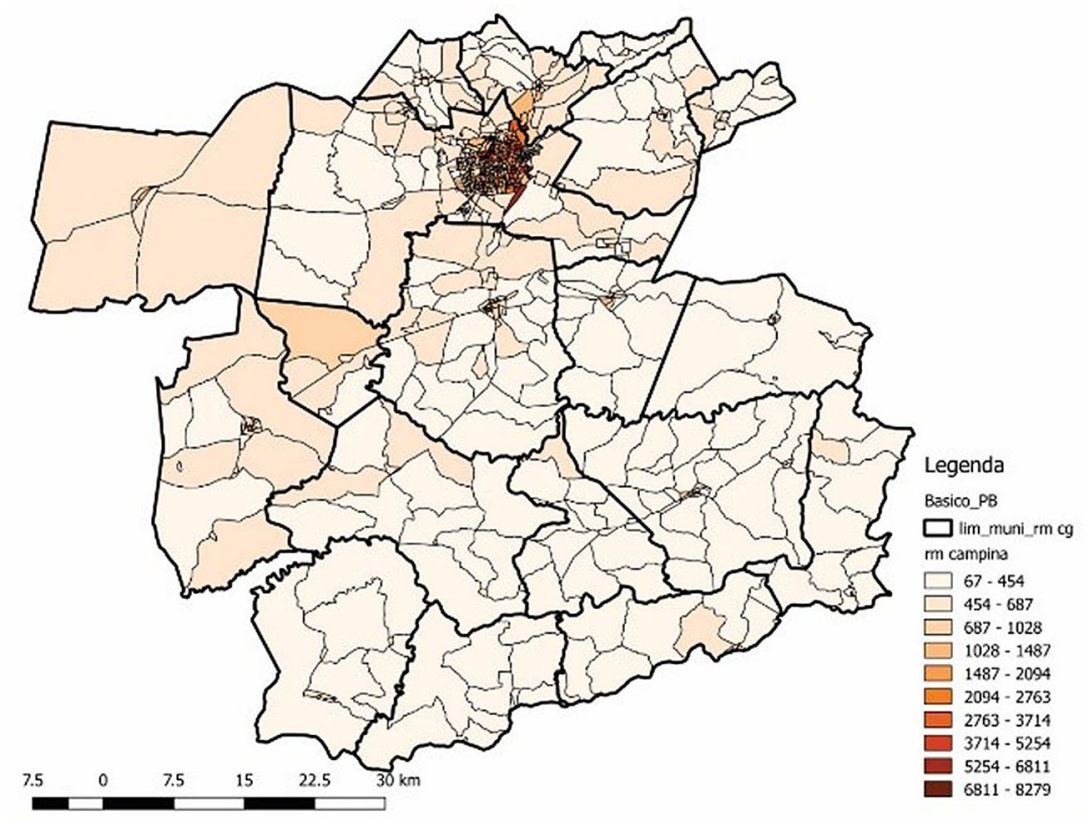

Fonte: Elaboração própria, em 2016, a partir da Base Cartográfica do IBGE (2010b) e de dados do censo de 2010 (IBGE, 2010). 
estado (atrás apenas da capital Salvador/BA) e a maior cidade do interior das regiões Norte, Nordeste, Centro Oeste e Sul do Brasil. Quando se analisa apenas a área urbana consolidada da RM, as áreas mais densas se encontram ao longo do anel rodoviário, especialmente na porção oeste. Por outro lado, o centro, de usos predominantemente comerciais, possui densidades inferiores a 48 hab/hec. Apesar da expansão da cidade se caracterizar por uma tendência a seguir em direção Leste (Souza e Santos, 2011), na representação (Figura 2), é possível visualizar também os eixos de expansão ao Norte (ao longo da BR-116) e ao Sul, em direção ao município de São Gonçalo dos Campos, com densidades médias e baixas, denotando o início dessa ocupação.

Para o Cariri/CE, o Crajubar congrega cerca de $76 \%$ da população da RM. Juazeiro do Norte contribui com cerca de $45 \%$ desse percentual e possui também a maior densidade de todos os municípios-sede de RM. Isso se dá pelo seu pequeno território (o menor da região) que possui cerca de $80 \%$ de área urbanizada. Ao observamos o mapa com a distribuição desses dados por setor censitário (Figura 2), é possível ver que no censo de 2010 ainda não há densidade nas áreas que correspondem à conurbação. Há duas hipóteses: a primeira, devido aos usos comerciais/serviços predominantes nas vias de ligação intermunicipal (conforme comentado no item anterior) e, a segunda porque esse processo ainda é embrionário, ou seja, condomínios e loteamentos presentes naqueles arredores são recentes e ainda estão parcamente ocupados. Traçando uma correlação com a distribuição de renda (Figura 1), os setores mais densos são aqueles de ocupação das faixas baixas e médias. As análises empíricas demonstram que as elites do Cariri se isolam em porções do espaço monofuncionais (onde não há sequer um pequeno comércio de apoio imediato às residências), compostas por grandes lotes (anteriormente identificados como chácaras, embora assista-se à gradativa subdivisão para a construção de condomínios residenciais) que possuem as amenidades climáticas proporcionadas pela proximidade com a Chapada do Araripe, que contribui para a valorização dos terrenos e aumenta a especulação imobiliária (Guegel, 2012).

Para a RM de Campina Grande/PB, o primeiro destaque a ser feito é a queda do percentual de população da cidade-sede em relação à população total. Enquanto nas demais RMINEs em análise essa percentagem está acima dos 70\%, em Campina Grande corresponde "apenas" a $63 \%$ da população total. Acredito que isso ocorra devido à quantidade de municípios constituintes dessa RM (19 no total), sendo que, destes, 16 têm população inferior a vinte mil habitantes. ${ }^{3}$ Analisando os dados espacializados (Figura 2), a proximidade das manchas densas dos municípios vizinhos indica uma conurbação física com Campina Grande. Porém, parece haver duas tendências distintas: a primeira se dá por uma atração entre o núcleo de Lago Seca (preexistente e consolidado) e a expansão norte de Campina; e a segunda, ao sul, verificada por um "espraiamento" da mancha urbana campinense sobre o território do município de Queimadas, visto que o núcleo desse município se encontra mais a sul.

A Raid possui características similares às demais RMINEs analisadas: altas concentrações populacionais no(s) município(s)-sede em contraponto a um entorno composto por densidades populacionais 
Figura 2 - Mapas de densidade populacional

(em habitantes por hectare) por setor censitário

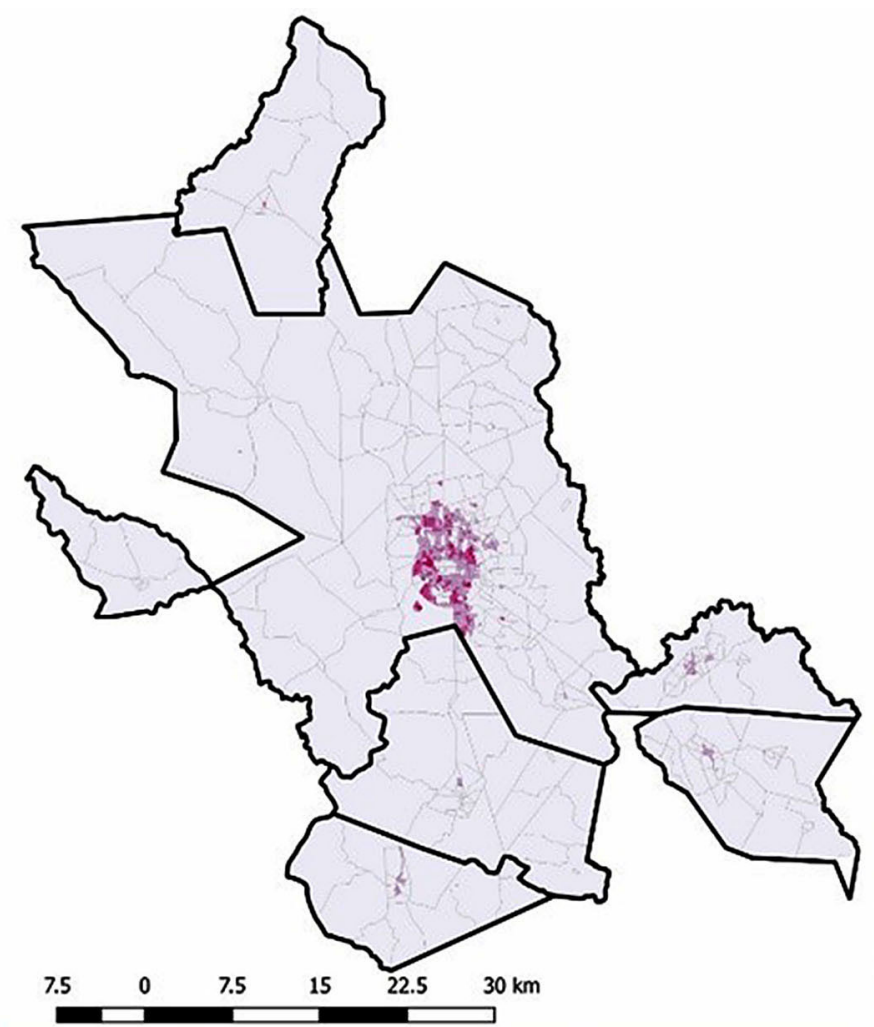

Legenda

$\square$ lim_mun_pm feira PM FEIRA DE SANTANA $0-48$

$48-118$

$118-201$

- $201-398$

$398-750$

\section{MAPA DE DISTRIBUIÇÃO DE DENSIDADE POPULACIONAL (HAB/HA) POR SETOR CENSITÁRIO NA RM FEIRA DE SANTANA/BA}

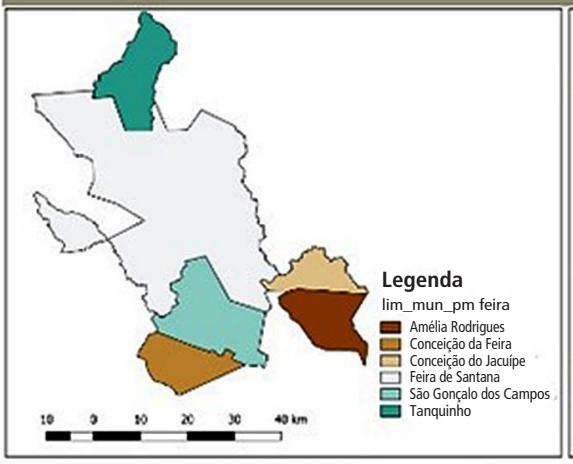

MAPA-CHAVE: MUNICIPIOS

CONSTITUINTES DA RM FEIRA DE

SANTANABA

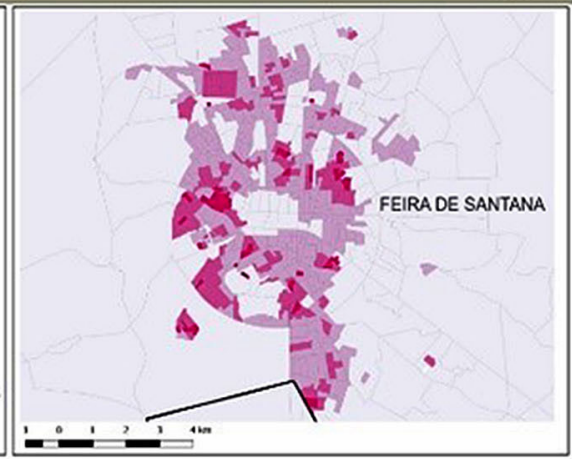

DETALHE DA DISTRIBUICCAO DE DENSIDADE POPULACIONAL (HAB/HA) POR SETOR CENSITÁRIO NA RM FEIRA DE SANTANABA 


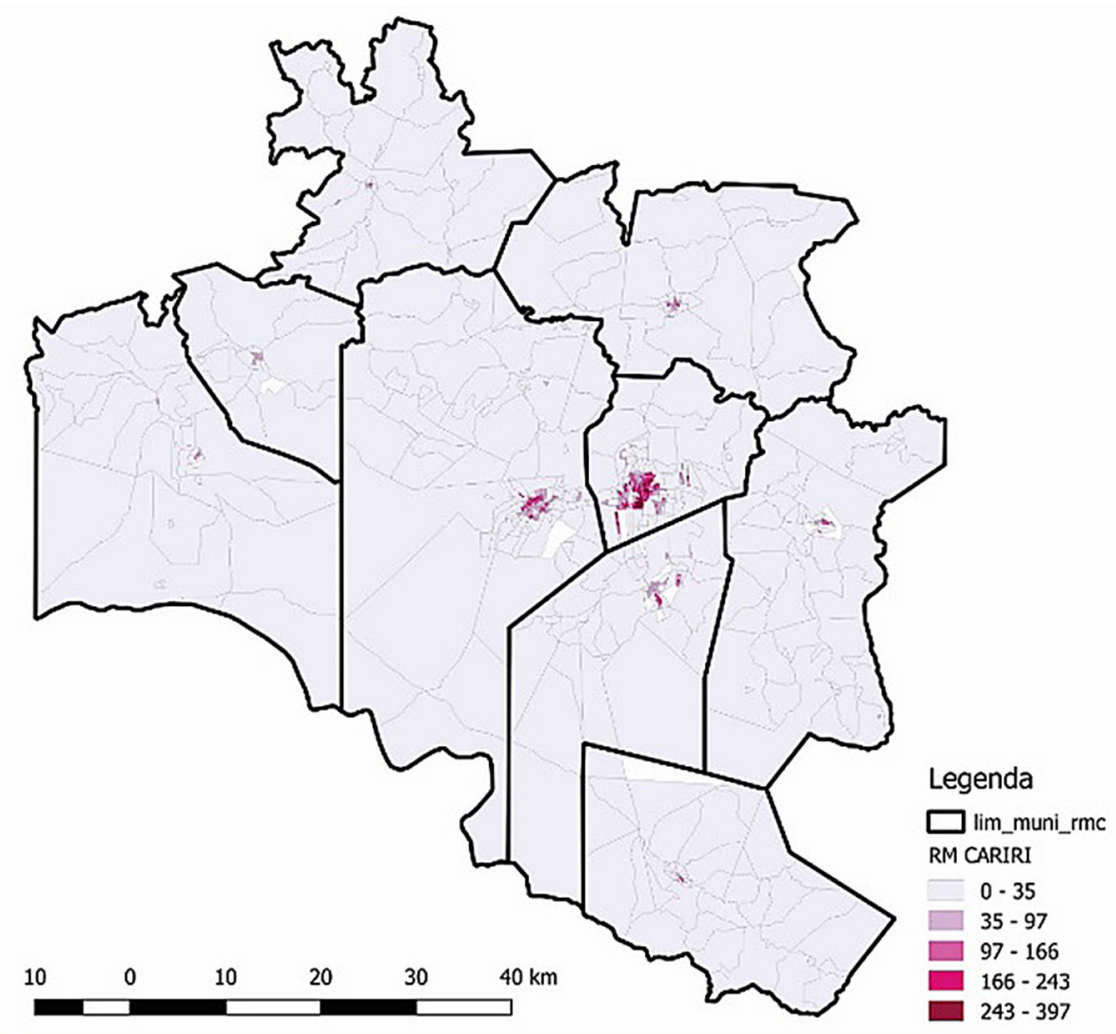

MAPA DE DISTRIBUIÇÃO DE DENSIDADE POPULACIONAL (HAB/HA) POR SETOR CENSITÁRIO NA RM CARIRI/CE

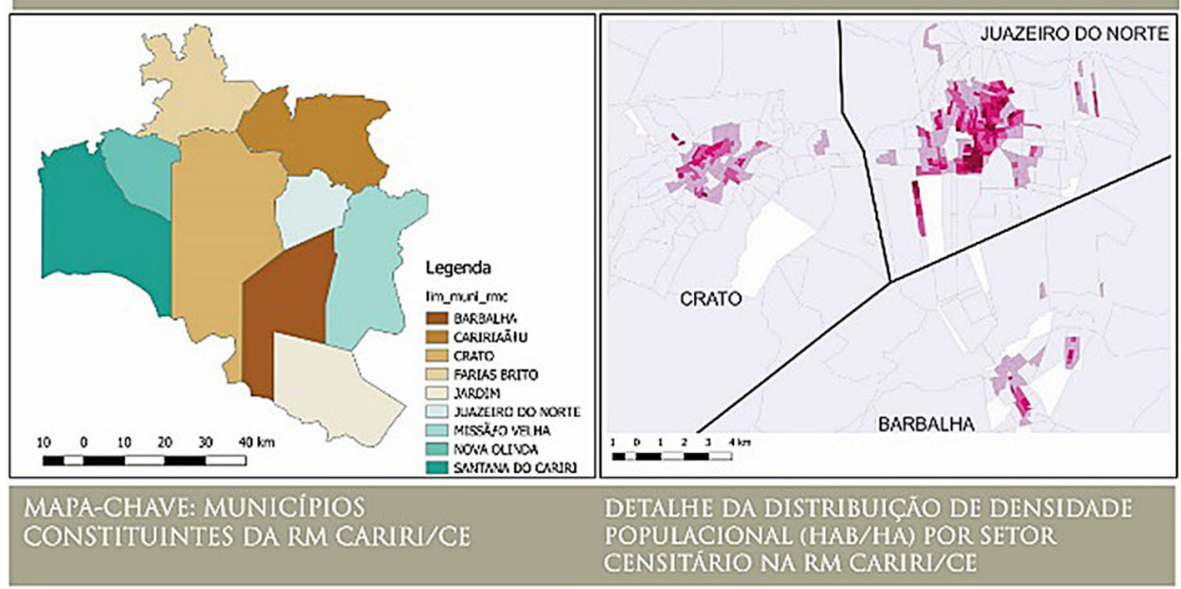




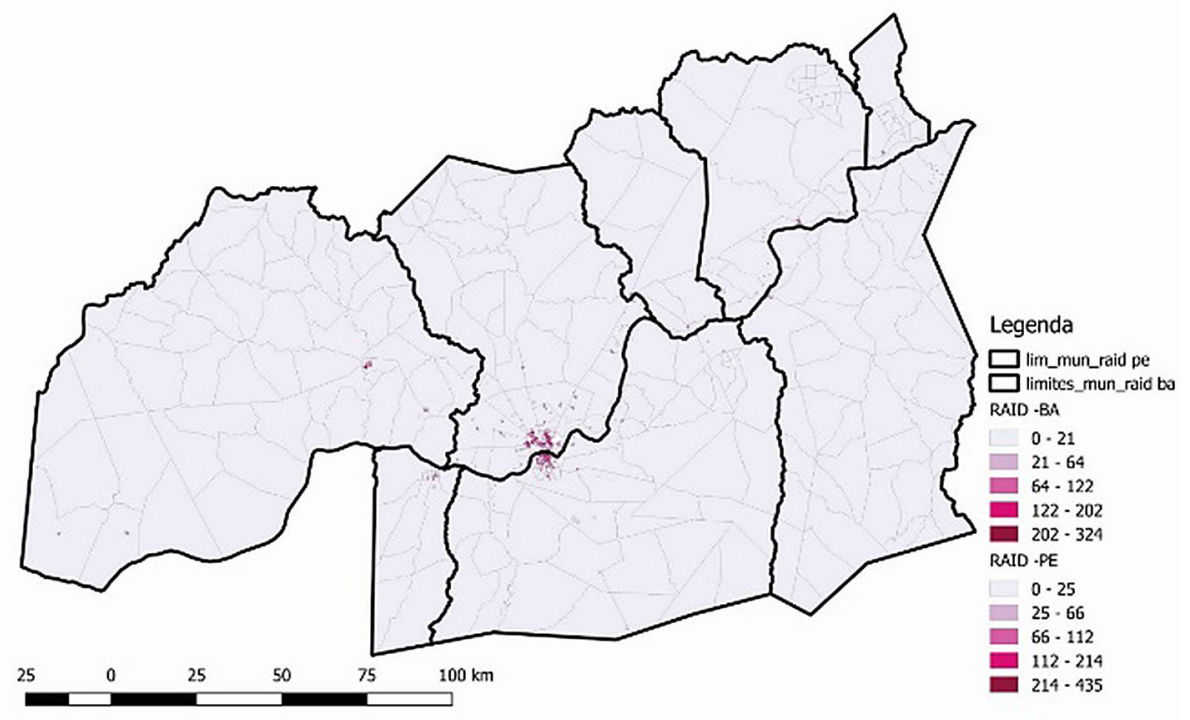

MAPA DE DISTRIBUICAO DE DENSIDADE POPULACIONAL (HAB/HA) POR SETOR CENSITÁRIO NA RAID DE PETROLINA/JUAZEIRO

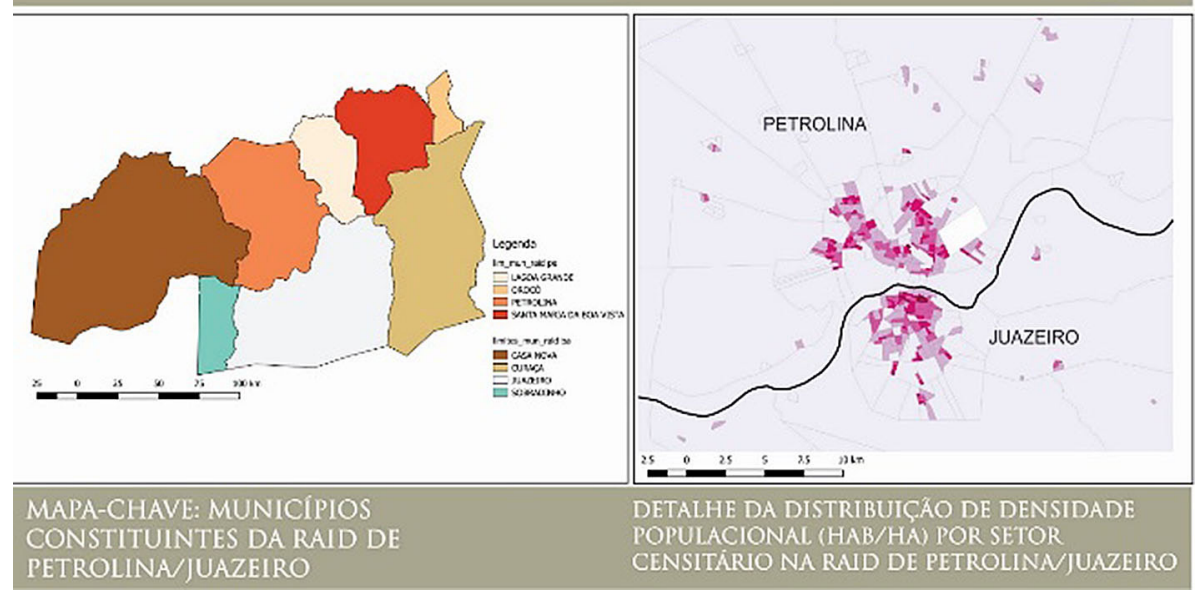




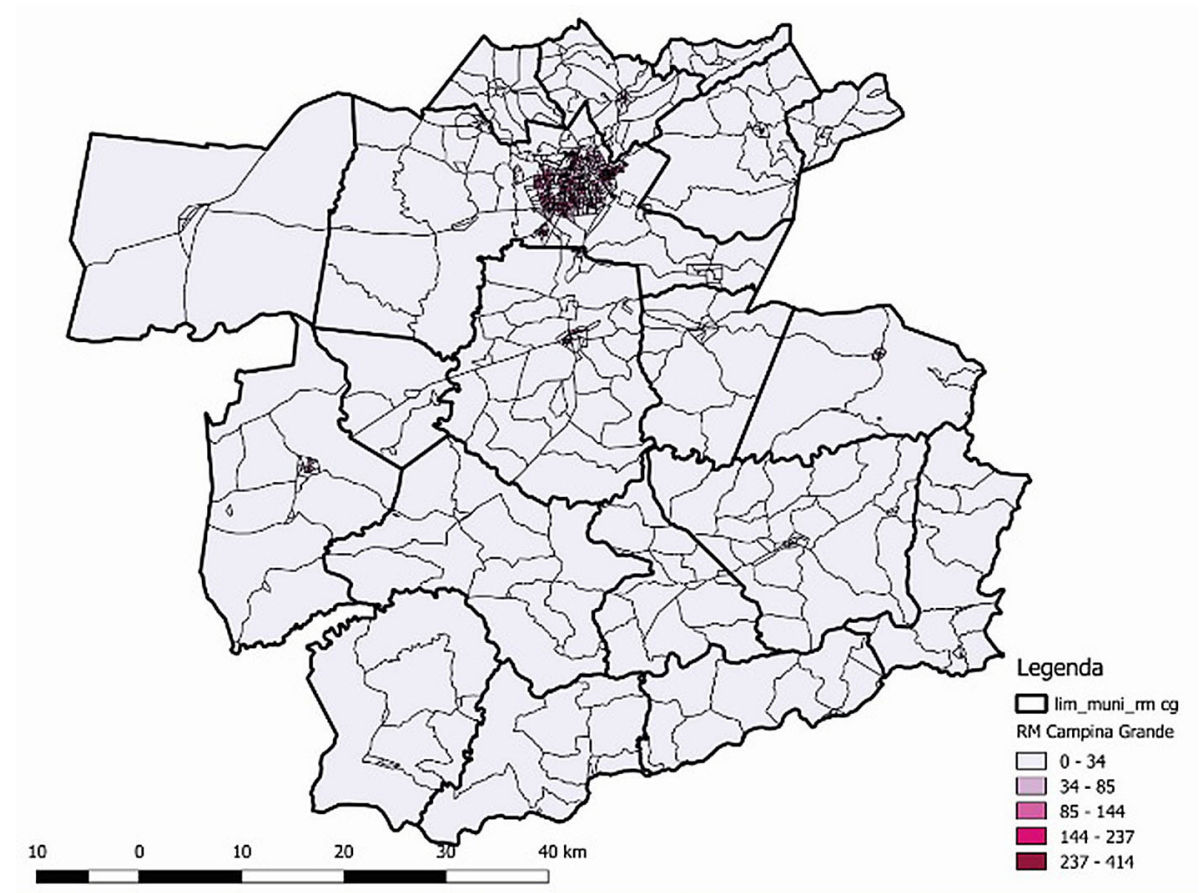

MAPA DE DISTRIBUICAÃO DE DENSIDADE POPULACIONAL

(HAB/HA) POR SETOR CENSITÁRIO NA RM CAMPINA GRANDE/PB

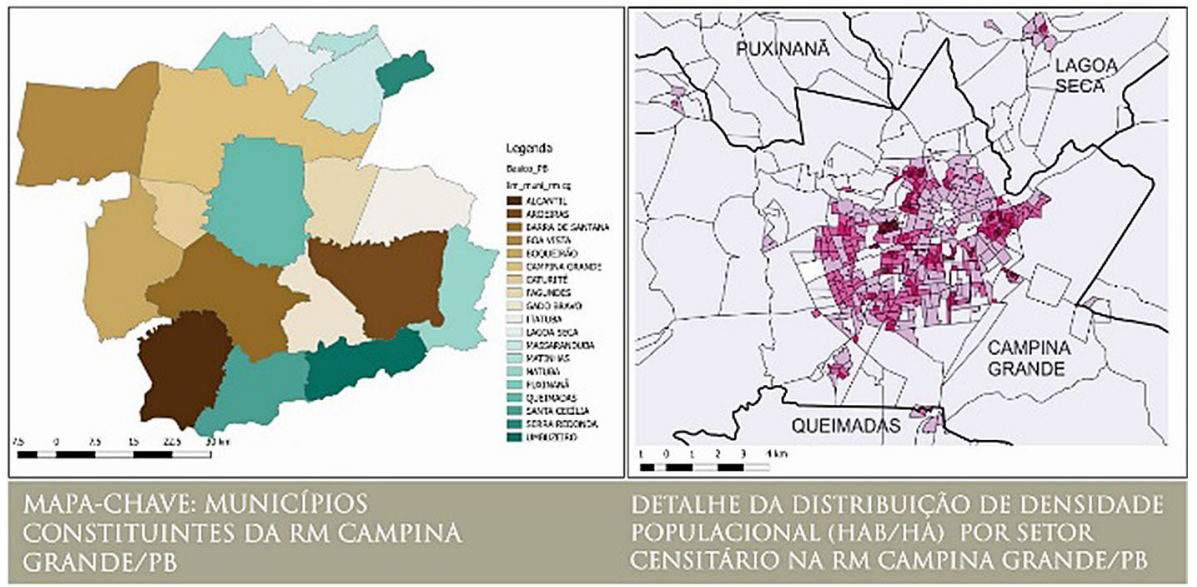

Fonte: Elaboração própria, em 2016, sob a Base Cartográfica do IBGE (2010) e os dados do censo de 2010. 
menores. A particularidade da Raid é o tamanho dos territórios municipais (somados, atingem mais de 33 mil quilômetros quadrados), o maior entre os analisados neste trabalho e um dos maiores do País. Uma das explicações é a preponderância agrícola dessa região, mas também remete à discussão sobre a heterogeneidade da divisão municipal brasileira.

0 Quadro 1 representa as variedades de tipologias de expansões do tecido urbano. A primeira delas, a verticalização, é um dos processos mais marcantes da imagem simbólica da metrópole: o aglomerado denso que se eleva aos céus. Como não pensar em São Paulo ou Nova York sem vir à mente a ideia da "selva de pedra" ? Há nos casos destacados duas escalas de verticalização: inicial (concentrada) e mediana (espalhada por vários bairros).

Os resultados foram heterogêneos, mas ressalto que as RMINEs que possuem conurbações consolidadas (Cariri/CE e Raid) apresentam estágios iniciais de verticalização. Minha hipótese é que, com a fluidez das malhas entre os municípios, as áreas de expansão horizontal tornam-se vastas, freando, a princípio, a necessidade de multiplicação do solo por meio de edifícios de apartamentos de alto padrão. Outra possível explicação da parca difusão da verticalização no interior diz respeito ao "modo de morar tradicional" das elites nordestinas de tradição rural, que vão preferir as mansões - numa atualização das chácaras do período colonial - preferencialmente em condomínios fechados que the agregam itens de segurança e lazer privado. É, portanto, grande o destaque desses empreendimentos nas localidades estudadas. Embora os padrões construtivos variem, todos eles deixam explícitos os processos de autossegregação que as faixas de maior renda impõem, por exemplo, através da utilização de áreas periféricas. 0 fato de as elites se separarem em determinadas áreas das cidades, simbolizando poder, status e distinção, não é novo e não pode ser creditado tão somente aos condomínios fechados. Entretanto, em outros períodos, as vias conservam-se abertas, e a possibilidade, por mais remota que fosse, de uma livre circulação de pedestres existia.

Essas novas áreas trazem à tona a discussão da nova relação entre o público e o privado, uma vez que esses empreendimentos transfiguram o sentido do público em diversas dimensões: criando o solo urbano de maneira privada; impedindo a livre circulação e o convívio democrático entre a população da cidade; transferindo para a esfera privada encargos que são de natureza pública e de acesso universal, como equipamentos sociais; enquanto, paradoxalmente, o poder público arca com o investimento na infraestrutura mais pesada, como vias e perimetrais que facilitam o acesso a essas novas urbanizações (Barcellos e Mammarella, 2007). Esse isolamento provoca cisões também no tecido social, visto que impede a copresença, dificultando as possibilidades de novas relações (Soja, 2000). É, até certo ponto, portanto, questionável o que Villaça (2001) denomina segregação voluntária, pois a população que opta por morar nesses condomínios não necessariamente tem plena consciência desses processos e é refem das escolhas do capital imobiliário que replica o discurso de medo e violência em seu marketing. 


\section{Quadro 1 - Comparativo entre as tipologias de expansão residencial}

\begin{tabular}{|c|c|c|c|c|}
\hline & $\begin{array}{l}\text { RM de Feira de } \\
\text { Santana/BA }\end{array}$ & RM do Cariri/CE & $\begin{array}{c}\text { RM Campina Grande/ } \\
\text { PB }\end{array}$ & $\begin{array}{l}\text { RAID de Petrolina/ } \\
\text { Juazeiro }\end{array}$ \\
\hline $\begin{array}{l}\text { Distribuição de } \\
\text { densidades e rendas }\end{array}$ & $\begin{array}{l}\text { A cidade-sede é } \\
\text { dominante em renda e } \\
\text { densidades }\end{array}$ & $\begin{array}{l}\text { A conurbação é } \\
\text { dominante em renda e } \\
\text { densidades }\end{array}$ & $\begin{array}{l}\text { A cidade-sede é } \\
\text { dominante em renda e } \\
\text { densidades }\end{array}$ & $\begin{array}{l}\text { A conurbação é } \\
\text { dominante em renda e } \\
\text { densidades }\end{array}$ \\
\hline Verticalização & $\begin{array}{l}\text { Mediana } \\
\text { Espalhada por diversos } \\
\text { bairros }\end{array}$ & $\begin{array}{l}\text { Inicial } \\
\text { Concentrada em alguns } \\
\text { bairros }\end{array}$ & $\begin{array}{l}\text { Mediana } \\
\text { Espalhada por diversos } \\
\text { bairros }\end{array}$ & $\begin{array}{l}\text { Inicial } \\
\text { Concentrada em alguns } \\
\text { bairros }\end{array}$ \\
\hline $\begin{array}{l}\text { Condomínios } \\
\text { fechados (médio } \\
\text { e alto padrão) }\end{array}$ & $\begin{array}{l}\text { Poucos } \\
\text { Periféricos } \\
\text { Alto/médio padrão } \\
\text { Auto segregados }\end{array}$ & $\begin{array}{l}\text { Poucos } \\
\text { Periféricos } \\
\text { Médio padrão } \\
\text { Auto segregados }\end{array}$ & $\begin{array}{l}\text { Poucos } \\
\text { Periféricos } \\
\text { Médio padrão } \\
\text { Auto segregados }\end{array}$ & $\begin{array}{l}\text { Poucos } \\
\text { Periféricos } \\
\text { Médio padrão } \\
\text { Chácaras } \\
\text { Auto segregados }\end{array}$ \\
\hline $\begin{array}{l}\text { Expansão residencial } \\
\text { de baixo padrão/ } \\
\text { favelização }\end{array}$ & $\begin{array}{l}\text { Periféricos } \\
\text { Financiamento MCMV } \\
\text { Favelização }\end{array}$ & $\begin{array}{l}\text { Periféricos } \\
\text { Financiamento MCMV }\end{array}$ & $\begin{array}{l}\text { Periféricos } \\
\text { Financiamento MCMV } \\
\text { Favelização }\end{array}$ & $\begin{array}{l}\text { Periféricos } \\
\text { Financiamento MCMV }\end{array}$ \\
\hline
\end{tabular}

Fonte: Elaboração própria, em 2017.

De certa maneira, esses condicionantes são replicados também nas áreas de habitação das faixas de renda baixas e medianas através da construção dos conjuntos habitacionais financiados principalmente pelo programa Minha Casa Minha Vida - MCMV. Embora a inserção de programas federais como esse tenha um importante papel em mitigar o déficit habitacional do País, a perda das qualidades espaciais é a crítica recorrente a sua atuação. No nível da edificação, há a homogeneização da arquitetura das unidades e, na escala da inserção urbana, sua localização periférica, distante da malha dotada de infraestrutura e mercado de trabalho, agrava problemas urbanos e sociais já insustentáveis em nossas cidades, replicando os bolsões de pobreza.

\section{Considerações finais}

Este artigo é um resumo de uma tese de doutoramento na qual se debruçou sobre referenciais empírico e analítico em busca da definição de um tipo metropolitano em termos demográficos e socioespaciais. Escalas ou tipificações de cidades são comuns nos estudos acerca da rede urbana, dos quais destaco Santos (1967), que conceituou como "metrópoles incompletas" aquelas que polarizam a região à sua volta, em oposição à ideia de "metrópoles completas", assim denominadas por congregarem equipamentos e estrutura complexa capazes de organizar o espaço nacional. Entretanto, uma dicotomia tão rígida não parece abarcar toda a realidade urbana brasileira. Não há apenas dois 
tipos de metrópoles, mas sim uma vasta gama de entretons entre o completo e o incompleto.

Para identificar tais nuanças metropolitanas, proponho um afastamento dos tradicionais critérios de mensuração urbana de densidade populacional e predominância das atividades industriais, como aqueles que subsidiaram a metodologia de formação das RMs nos anos 1970 (Galvão et al., 1969 apud Branco, Pereira e Nadalin, 2013), embora isso possa soar, em princípio, contraditório, uma vez que a queixa principal, ao longo deste trabalho, resida na falta de critérios de definição para os arranjos metropolitanos ou que, quando há tais aparatos técnicos, podem ser tecidas críticas quanto a sua pertinência e qualidade, visto que os resultados obtidos, quando aplicados, não traduzem a heterogeneidade da metropolização brasileira. Portanto, é preciso ter em mente que, no momento em que as primeiras RMs são institucionalizadas, prevalece a ideologia tecnocrática que gerou perfeitas peças técnico-científicas cujo destino foi - com algumas raras exceções - 0 engavetamento (Villaça, 1999). Mesmo com os avanços normativos do Estatuto das Cidades (Brasil, 2001) e das Metrópoles (Brasil, 2015), as políticas urbanas e o planejamento no Brasil foram, até 2016, marcados por um ideário desenvolvimentista, embora tecnocrático e com incipiente participação popular. Diante da crise política por que passa o Brasil hoje, porém, a situação pode ser agravada por um provável retrocesso normativo-estatutário. Porquanto a instituição de nossas regiões metropolitanas é calcada principalmente em interesses econômicos e políticos que, à primeira vista, desvinculam-se de critérios técnicos. Isso é esperado, visto que, tal como um Plano Diretor, a definição de RMs não é um artifício puramente técnico-científico, mas principalmente uma peça política.

Entretanto, é inegável que as RMINEs estudadas neste trabalho apresentam concentrações demográficas e socioeconômicas que lhes dão um papel polarizador ante a rede urbana do Nordeste, que lhes confere uma hierarquia intermediária entre 0 interior e as capitais em estudos, como o Regic (IBGE, 2008). Soma-se a isso a existência de diversos indícios no ambiente edificado, que dão suporte a essa posição mediana na rede urbana. Entender esses padrões é, portanto, de suma importância para deixarmos de nos prender a uma simples nomenclatura de RMs (ou aglomerações urbanas, como proposto no Estatuto da Metrópole), para nos atermos a características socioespaciais como base do planejamento urbano.

Os achados demonstram que há um tipo metropolitano de médio porte no interior do Nordeste que tem tantas caraterísticas: 1) suas sedes são núcleos urbanos (ou conurbações) consolidados e densamente ocupados em relação ao seu entorno, cujas populações totais configuram entre 500 mil e 700 mil habitantes; 2) esses núcleos congregam equipamentos, serviços e empregos que atendem a uma escala regional em uma relação direta com sua centralidade topológica; 3) representam uma dominância socioeconômica e funcional dessas cidades-sede sobre suas hinterlândias, exacerbando as desigualdades intrarregionais; 4) subsidiando também processos de desigualdades intraurbanas; 5) por meio de segregação socioespacial, entre as faixas de renda e aos acessos a bens e serviços que cada grupo social dispõe; 6) calcado em uma nova produção habitacional - regular ou irregular, vertical 
Figura 3 - Esquema conceitual do tipo metropolitano do interior do Nordeste

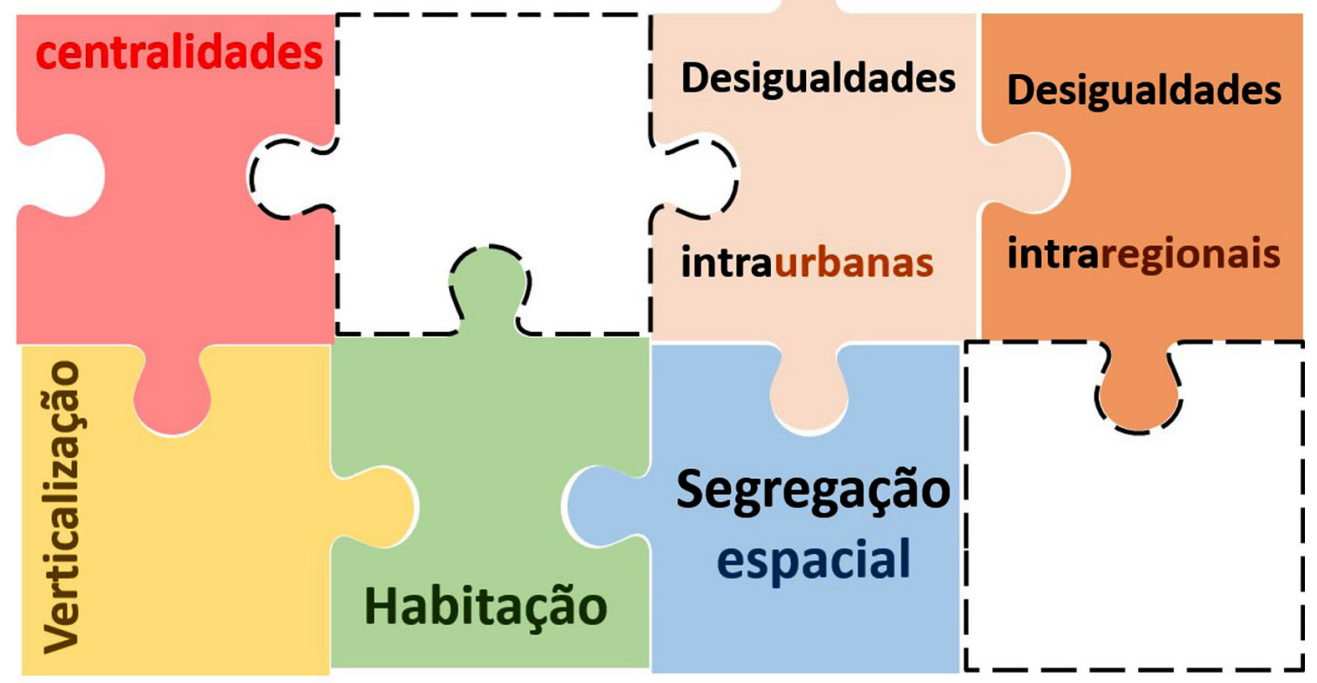

Fonte: Elaboração própria, em 2016.

e horizontal - que estabelece novas relação entre o público e o privado (Figura 3).

Há algumas limitações nas variáveis apresentadas, especialmente quando repensamos as diferenças inter-regionais brasileiras. Sugere-se, como continuidade a essa pesquisa, a utilização de ferramentas e medidas que possibilitem inserir os casos aqui analisados num comparativo com as demais cidades, aglomerações e RMs brasileiras já estudadas. Essa abordagem comparativa poderá ser de grande valia para estabelecer a escala de nuanças metropolitanas do País como um todo.

Porém, dentre os padrões aqui trabalhados, destaco suas centralidades que congregam acessibilidade e funcionalidades em uma escala regional, que geram fluxos e movimentos pendulares em busca dos empregos que ali se localizam. Nas aglomerações estudadas, há uma grande oferta de bens e serviços públicos e privados, representada pelos grandes equipamentos comerciais, no fortalecimento das instituições de educação (especialmente de nível superior) e da rede de saúde. Essa característica de atração funcional exacerba as desigualdades regionais, num processo retroalimentado pela desigual distribuição de rendas e acessos a infraestruturas e serviços urbanos. Essa dinâmica socioeconômica é global, mas produz claros reflexos regionais. Os espaços urbanos precisam ser (re)adequados, em nível local e regional, às formas de organização da produção em escala 
global. Entretanto, esse processo exacerba as diferenças intraurbanas e entrar-regionais, que se expressam principalmente na disposição dos novos investimentos na aglomeração regional, ampliando a concentração (de equipamentos, empregos, bens e serviços) e a centralização do dinamismo regional nas cidades-sede.

Esse poder de polarização é responsável pela expansão dos tecidos urbanos e pelos processos de conurbação. Os processos mais antigos e consolidados são o Crajubar/CE e Petrolina-Juazeiro. Uma hipótese que pode explicar essa diferenciação é a sua localização: distantes das capitais - Juazeiro do Norte/CE é separado de Fortaleza por cerca de $500 \mathrm{Km}$; Juazeiro/BA também fica distante cerca de $500 \mathrm{~km}$ de Salvador; e Petrolina está a mais de $700 \mathrm{~km}$ do Recife - e locadas em meio à vasta extensão sertaneja de caracteres rurais. Ao longo da sua formação urbana, essas aglomerações tiveram que responder a funções e serviços que atendiam também as suas circunvizinhanças.

As demais RMs e cidades analisadas estão relativamente próximas das capitais estaduais (por exemplo, Campina Grande/PB é distante de João Pessoa cerca de $130 \mathrm{~km}$ e está a $190 \mathrm{~km}$ do Recife, enquanto a RM de Feira de Santana e a RM de Salvador têm territórios praticamente contínuos). Nesses casos, a força das capitais, que possuem grande poder polarizador em escala nacional, parece expandir-se e influenciar o crescimento de suas hinterlândias. 0 ponto que se abre para investigação é: por que motivo o desponte foi Campina Grande ou Caruaru e não uma outra cidade vizinha? Acredita-se que a resposta a essa pergunta resida nos processos de formação histórica dessas cidades, enquanto ocupações mais antigas (e, portanto, mais consolidadas) e nas suas forças políticas que carrearam, ao longo dos anos, recursos e equipamentos que impulsionaram seu desenvolvimento e diferenciação das demais cidades do entorno.

Retomando os processos de expansão urbana, percebe-se nos casos analisados que eles se dão principalmente por novas áreas residenciais que mitigam o déficit habitacional do País por meio do MCMV ou por atender aos novos modos de morar das elites, apartadas da cidade por meio de um arquipélago carcerário (cf. Soja, 2000) de condomínios e novos espaços de lazer e consumo, ilustrados pelos shoppings. 0 que se apresenta aqui são os efeitos da globalização e da decorrente massificação cultural, transposta na estrutura urbana como processos de urbanização (cf. Muñoz, 2008). Embora as intensidades sejam discrepantes - obviamente Feira de Santana/BA ou Campina Grande/PB não são capazes de exercer a mesma polarização econômica de uma cidade global como Berlim, por exemplo, e, portanto, não expressam tantos espaços urbanos que respondam a uma escala além da nacional -, é possível perceber apropriações locais dos conceitos e ações de gestão e produção urbana no contexto das trocas globais.

Portanto, há metrópoles no interior do Nordeste. Elas não estão consolidadas como os grandes centros do País, mas já evidenciam os mesmos desafios que se impõem à questão metropolitana do Brasil. Essas batalhas são múltiplas e complexas, mas destaca-se o processo de integração política entre os municípios, extremamente necessário e urgente para o enfrentamento de problemas de ordem socioeconômica e de gestão dos serviços compartilhados, pois estes exigem cada vez mais a participação do conjunto metropolitano. 


\section{Ana Paula Campos Gurgel}

Universidade de Brasília, Faculdade de Arquitetura e Urbanismo, Departamento de Teoria e História da Arquitetura e Urbanismo. Brasília, DF/Brasil.

prof.anapaulagurgel@gmail.com

\section{Notas}

(1) A origem da palavra metrópole remonta à Grécia antiga e epistemologicamente fica clara a significação de cidade-mãe: o prefixo grego metra - que significa mãe, ventre - e o radical polis - que remete diretamente a cidade, urbe.

(2) Entende-se, portanto, o termo "médio" como referência à posição que essas cidades exercem na rede urbana: uma mediação entre os grandes centros urbanos e as pequenas aglomerações populacionais do interior.

(3) Municípios de pequeno porte estão presentes em praticamente todas as aglomerações estudadas (capitais e interioranas), com exceção da RM de Salvador/BA, o que traz à tona a discussão acerca dos critérios de delimitação das RM's no país. Não quero dizer com isso que o recorte populacional deve ser determinante ou que deva ser completamente desconsiderado (como parece acontecer desde a CF 88), mas que essa definição deve ser pautada sobretudo em indícios socioespaciais de metropolização.

\section{Referências}

ARAÚJO, G. J. F. de e SILVA, M. M. da (2013). Crescimento econômico no semiárido brasileiro: o caso do polo frutícola Petrolina/Juazeiro. Caminhos de Geografia. Uberlândia, v. 14, n. 46, pp. 246-264. Disponível em: <www.seer.ufu.br/index.php/ caminhosdegeografia/article/ download/18291/12824>. Acesso em: 28 maio 2016.

ARMSTRONG, W. e McGEE, T. G. (1968). Revolutionary change and the third world city: a theory of Urban Involution. Civilisations, v. 18, n. 3, pp. 353-378. Disponível em: <https://www.jstor.org/ stable/41231140?seq=1\#page_scan_tab_contents>. Acesso em: 10 jul 2016.

BARCELLOS, T. M. de e MAMMARELLA, R. (2007). O significado dos condomínios fechados no processo segregação espacial nas metrópoles. ENCONTROS NACIONAIS DA ANPUR, 12. Anais... Disponível em: <http://unuhospedagem. com.br/ revista/ rbeur/ index.php/ anais/article/view/3010>. Acesso em: 5 set 2016. 
BRANCO, M. L. G. C., PEREIRA, R. H. M. e NADALIN, V. G. (2013). “Rediscutindo a delimitação das Regiões Metropolitanas no Brasil: um exercício a partir dos critérios da década de 1970". In: FURTADO, B. A., KRAUSE, C. e FRANÇA, K. C. B. de (eds.). Território metropolitano, políticas municipais: por soluções conjuntas de problemas urbanos no âmbito metropolitano. Brasília, Ipea.

BRASIL (1988). Constituição da República Federativa do Brasil. Organização de Alexandre de Moraes. São Paulo, Atlas.

(2001). Lei no 10.257, de 10 de julho de 2001. Regulamenta os arts. 182 e 183 da Constituição Federal, estabelece diretrizes gerais da política urbana e dá outras providências. Disponível em: <http://www.planalto.gov.br>. Acesso em: 30 jan 2015.

(2015). Lei no 13.089, de 12 de janeiro de 2015. Institui o Estatuto da Metrópole, altera a Lei no 10.257, de 10 de julho de 2001, e dá outras providências. Disponível em: <http://www.planalto. gov.br>. Acesso em: 30 jan 2015

CARLOS, A. F. A. (1994). A (re)produção do espaço urbano. São Paulo, Edusp.

CARMO JÚNIOR, J. B. (2014). A forma do privilégio: renda, acessibilidade e densidade em Natal-RN. Tese de Doutorado. Natal, Universidade Federal do Rio Grande do Norte. Disponível em: <http:// repositorio.ufrn.br/jspui/handle/123456789/12324>. Acesso em: 20 jan 2016.

FERRARI, C. (2004). Dicionário de urbanismo. São Paulo, Disal.

FIRKOWSKI, O. L. C. de F. (2012). Por que as Regiões Metropolitanas no Brasil são Regiões, mas não são Metropolitanas. Revista Paranaense de Desenvolvimento. Curitiba, n. 122, pp. 19-38. Disponível em: <http://www.ipardes.pr.gov.br/ojs/index.php/ revista paranaense/ article/view/465>. Acesso em: 29 jun 2013.

GURGEL, A. P. C. (2012). Entre serras e sertões: a(s) (trans)formação(ões) de centralidade(s) da Região Metropolitana do Cariri/CE. Dissertação de Mestrado. Natal, Universidade Federal do Rio Grande do Norte. Disponível em: <http://repositorio.ufrn.br:8080/jspui/handle/123456789/12378>. Acesso em: 25 jun 2015.

(2016). As metrópoles do interior e o interior das metrópoles. Tese de Doutorado. Brasília, Universidade de Brasília. Disponível em: <http://repositorio.unb.br/handle/10482/22370>. Acesso em: 5 abr 2017.

HOLANDA, F. de (2002). O espaço da exceção. Brasília, Editora da Universidade de Brasília (Coleção Arquitetura e Urbanismo).

IBGE (2008). Regiões de Influência das Cidades 2007. Rio de Janeiro, IBGE. Disponível em: <http:// www.mma. gov.br/estruturas/PZEE/_arquivos/regic_28.pdf>. Acesso em: 13 jan 2016.

(2010a). Contagem da População 2010. Disponível em: <http://www.censo 2010.ibge.gov.br/ sinopse>. Acesso em: 10 jun 2011.

(2010b) Censo Demográfico 2010: Resultados Gerais da Amostra por áreas de ponderação. Disponível em: <http://ibge.gov.br /home /estatistica/ populacao/ censo2010/ resultados_ gerais_amostra_areas_ponderacao/default.shtm>. Acesso em: 13 jul 2016.

(2012). Produto interno bruto dos municípios 2010. Rio de Janeiro, IBGE. Disponível em: <http:// www.ibge.gov.br/home/estatistica/economia/pibmunicipios/2010/default.shtm>. Acesso em: 8 ago 2015. 
IBGE (2013). Dez mandamentos da arquitetura. Brasília, FRBH.

(2014). Estimativas da população residente no Brasil e unidades da federação com data de referência em 1 o de julho de 2014. Disponível em: <ftp://ftp.ibge.gov.br/Estimativas_de_ Populacao/Estimativas_2014/estimativa_dou_2014.pdf>. Acesso em: 21 jun 2015

IPEA, IBGE, UNICAMP (2001a). Caracterização e tendências da rede urbana do Brasil: configurações atuais e tendências da rede urbana vol. 1. Brasília, Ipea.

(2001b). Caracterização e tendências da rede urbana do Brasil: redes urbanas regionais: Norte, Nordeste e Centro-oeste. Brasília, Ipea.

LENCIONI, S. (2006). “Da cidade e sua região à cidade-região”. In: SILVA, J. B., LIMA, L. e ELIAS, D. (orgs.). Panorama da Geografia Brasileira I. São Paulo, Annablume.

MEDEIROS, V. A. S. de (2006). Urbis brasiliae ou sobre cidade do Brasil. Inserindo assentamentos urbanos do país em investigações configuracionais comparativas. Tese de Doutorado. Brasília, Universidade de Brasília. Disponível em: <http://repositorio.unb.br/handle/10482/1557>. Acesso em: 25 dez 2016.

MUÑOZ, F. (2008). Urbanalización: paisajes comunes, lugares globales. Barcelona, Gustavo Gilli.

ONU (2014). Department of Economic and Social Affairs, Population Division World urbanization prospects. The 2014 revision. New York: United Nations, 2015. Disponível em: <http://esa. un.org/unpd/wup/ Publications/Files/WUP2014-Report.pdf>. Acesso em: 11 jan 2016.

RIBEIRO, L. C. de Q., MOURA, R. e DELGADO, P. et al. (2012). Níveis de integração dos municípios brasileiros em RMs, RIDEs e AUs à dinâmica da metropolização. Rio de Janeiro. Disponível em: <http://observatoriodasmetropoles.net/download/ relatorio_integracao.pdf>. Acesso em: 25 jun 2013.

SANTOS, M. (1967). Crescimento nacional e a nova rede urbana: o exemplo do Brasil. Revista Brasileira de Geografia, v. 29, n. 4, pp. 78-92.

(1989). A Metrópole corporativa, fragmentada. São Paulo, Studio Nobel.

(1993). "Involução metropolitana e economia segmentada. O caso de São Paulo". In: RIBEIRO, A. C. T. et al. (orgs.). Seminário Metropolização e Rede Urbana, Perspectivas dos anos 90. Rio de Janeiro, Ippur/UFRJ.

(1997). Pensando o espaço do homem. São Paulo, Hucitec.

SOARES, B. R. (1998). Repensando as cidades médias brasileiras no contexto da globalização. Palestra proferida junto ao Programa de Pós-graduação em Geografia em 18 jun 1998. Formação, Presidente Prudente, n. 6, 1999. Disponível em: <http://revista.fct.unesp.br/ index.php/ formacao/ article/view/1167/1168>. Acesso em: 28 abr 2015.

SOJA, E. W. (2000). Postmetropolis: critical studies of cities and regions. Malden (Massachussets), Blackwell Publishers.

SOUZA, B. de S. e SANTOS, R. L. (2011). Análise da expansão urbana de Feira de Santana através de condomínios fechados. In: 11ㅇ SEMINÁRIO URBANISMO NA BAHIA: DIREITO À CIDADE, CIDADE DO DIREITO. Anais... Salvador, EDUFBA, v. 1. pp. 1-13. Disponível em: <http://www.ppgau.ufba. br/urba11/>. Acesso em: 10 jun 2016. 
SPÓSITO, M. E. B. (2010). Desafios para o estudo das cidades médias. In: SEMINÁRIO INTERNACIONAL DE LA RED IBEROAMERICANA DE INVESTIGADORES SOBRE GLOBALIZACIÓN Y TERRITÓRIO, 11. Anais... Mendoza, UNCUYO - Universidad de Cuyo, pp. 1-18.

VILLAÇA, F. (1999). "Uma contribuição para a história do planejamento urbano no Brasil". In: DEAK, C. e SCHIFFER, S. R. (orgs.). O processo de urbanização no Brasil. São Paulo, Fupam/ Edusp, pp. 169-244.

(2001). Espaço intra-urbano no Brasil. São Paulo, Studio Nobel/Fapesp/Lincoln Institute.

TEIXEIRA, A. C. W. (2005). Região metropolitana: instituição e gestão contemporânea-dimensão participativa. Belo Horizonte, Fórum.

Texto recebido em 22/maio/2017

Texto aprovado em 24/ago/2017 